\title{
The Implications of the Court of Appeal Decision in Ladele And other Case Law Developments ${ }^{1}$
}

\author{
Russell Sandberg \\ Lecturer in Law, \\ Cardiff University
}

\section{Introduction}

The law prohibiting discrimination on grounds of religion or belief is currently found in the Employment Equality (Religion or Belief) Regulations 2003 and Part 2 of the Equality Act 2006. This law has led to a significant amount of litigation in the employment tribunals and now some cases are beginning to be heard on appeal by higher courts. The purpose of this paper is to provide an update and critique of recent developments with particular reference to the decision of the Court of Appeal in Ladele v London Borough of Islington. ${ }^{2}$

\section{Defining 'Religion or Belief'}

Aside from Ladele, there have been some important developments concerning the definition of 'religion or belief' at the Employment Appeal Tribunal (EAT). In Greater Manchester Police Authority $v$ Power $^{3}$ it was held that a belief in spiritualism and the philosophical belief in life after death and psychic powers fell within the Employment Equality (Religion or Belief) Regulations 2003. More importantly, in Grainger PLC v Nicholson ${ }^{4}$, the Employment Appeal Tribunal concluded that an asserted belief in man-made climate change, together with the alleged resulting moral imperatives arising from it, was capable of constituting a 'philosophical belief' for the purpose of the 2003 Regulations because it met the criteria laid out by the Article 9 jurisprudence of the European Convention on Human Rights (ECHR) which was directly relevant.

This is questionable, however, given that there are notable differences between discrimination law and human rights law in relation to definition. Unlike the ECHR, domestic discrimination law defines 'belief' as being 'any religious or philosophical belief', ${ }^{5}$ rather than a world view and Employment Tribunal (ET) decisions have held that national beliefs

\footnotetext{
${ }^{1}$ A paper presented to the Centre for Law and Religion's Interfaith Legal Advisers Network (01.03.2010).

2 [2009] EWCA (Civ) 1357.

3 [2009] EAT 0434/09/DA (12 November 2009).

4 [2009] UKEAT 0219/09/ZT (3 November 2009).

${ }^{5}$ Equality Act s44, s77(1).
} 
(Williams $v$ South Central Limited ${ }^{6}$ ) and political beliefs (Baggs $v$ Fudge ${ }^{7}$ ) are outside this definition. By contrast, Strasbourg has made it plain that political beliefs are considered to be 'beliefs' under Article 9 in the ECHR jurisprudence. ${ }^{8}$

\section{Direct Discrimination}

Direct discrimination occurs where A treats B less favourably (on grounds of religion or belief) than they would treat others in circumstances which are materially the same. Direct discrimination cannot be justified: there is no defence of reasonableness. The claimant must prove facts from which the Tribunal could conclude that unlawful discrimination has occurred. If the claimant makes such a prima facie case, then the burden of the proof passes to the respondent.

Direct discrimination claims are seldom successful. In most cases, they fail because the actions of the defendant are not on grounds of religion. An example of this can be found in Ladele.

To remind you of the facts of the case: Ladele, a Registrar, refused on grounds of conscience to perform civil partnership ceremonies. When Islington Council insisted that she should undertake at least some of these duties and disciplined her, threatening her with dismissal, she alleged that she had suffered discrimination on the grounds of religion or belief under the Employment Equality (Religion or Belief) Regulations 2003.

Although the original Employment Tribunal concluded that the claimant had suffered direct and indirect discrimination and harassment on grounds of religion or belief, both the Employment Appeal Tribunal and the Court of Appeal have held that the Tribunal had erred in law and substituted a finding of no discrimination.

Focussing upon the claim of direct discrimination, the EAT noted that the crucial question for the Tribunal to determine was the reason why the claimant was treated as she was. In order to establish discrimination on a prohibited ground (such as religion or belief), the Tribunal must be satisfied that the prohibited ground is one of the significant reasons for the treatment. The

\footnotetext{
${ }^{6}$ ET, Case Number: 2306989/2003 (16 June 2004)

${ }^{7}$ ET, Case Number: 1400114/2005 (23 March 2005)

${ }^{8}$ X v Austria (1963) 13 CD 42.
} 
EAT found that the Tribunal had confused the claimant's reasons for acting as she did (which were on grounds of religion) with the council's reasons for treating the claimant as they did (which were on grounds of her conduct not her belief).

The Court of Appeal agreed that the focus of the enquiry was why the direct discrimination occurred. ${ }^{9}$ The 'explanation given by the employer for the less favourable treatment' must be the Ladele's religious beliefs. ${ }^{10}$ In determining this, remarks made to Ladele should not be taken out of context. It must be shown that those 'responsible for the acts of alleged discrimination were motivated by Ms Ladele's religious beliefs, rather than by her refusal to officiate at civil partnerships'. ${ }^{11}$ The Court of Appeal dismissed the argument that Ladele could not have been required to carry out civil partnership duties as it was not part of her job description by reference to the fact that she 'was quite prepared to carry out, and indeed did carry out, various functions which were not within the ambit of her contract'.

The decision here by both the EAT and Court of Appeal seems correct. This was clearly not a case of direct discrimination. The Council did not treat Ladele less favourably on grounds of religion. Both the Court of Appeal and the EAT held that a failure to accommodate religious difference rather than a complaint that the claimant had been discriminated against because of that difference will not amount to direct discrimination. Treating people in the precisely the same way cannot constitute direct discrimination. ${ }^{12}$ However, I am uneasy as to parts of the reasoning both the EAT and Court of Appeal. The comments about not making remarks out of context could provide a barrier to making a successful claim. The focus upon whether defendant's the actions were 'motivated' by Ladele's beliefs seems to create a rather large hurdle. ${ }^{13}$ Does discriminating on grounds of religion require you to be motivated by that person's religion? ${ }^{14}$ Most of all, however, I find it of concern how the fact that Ladele had been willing to carry out functions outside her contract was used against her. I don't think this mattered in relation to direct discrimination, but I think the contract argument should have been afforded more weight in relation to indirect discrimination.

\footnotetext{
${ }^{9}$ Para 30.

${ }^{10}$ Paras 30, 33.

${ }^{11}$ Para 36.

12 Para 29.

${ }^{13}$ Note, however, the decision of the House of Lords in $R$ (on the application of) v JFS Governing Body \& Anor [2009] UKSC 15.

${ }^{14}$ The word 'motivated' is also strange in that it has been long held that Article 9 protects acts that manifest one's beliefs rather than those merely motivated by them.
} 


\section{Indirect Discrimination}

Indirect discrimination occurs where A applies or would apply a provision, criterion or practice (a PCP) equally (i) which puts persons of B's religion or belief at a particular disadvantage compared with others; (ii) which puts B at that disadvantage; and (iii) which A cannot show to be a proportionate means of achieving a legitimate aim. Indirect discrimination can be justified, for example, by security or health and safety concerns.

There have been a number of important cases concerning indirect discrimination, including successful ET decisions in relation to working hours ${ }^{15}$ and the High Court decision in $R$ (on the application of Watkins-Singh) $v$ The Governing Body of Aberdare Girls' High School ${ }^{16}$ holding that a ban on a Sikh's kara bangle at school was discriminatory.

Also of interest is the recent Court of Appeal decision in Eweida v British Airways ${ }^{17}$ which confirmed that solitary disadvantage is not sufficient. There needs to be proof that people who share the claimant's religion or belief would be disadvantaged. ${ }^{18}$ If one accepts that a ban on wearing a cross would not disadvantage Christians as a whole, this seems sound. But does this mean that new individual beliefs will not be protected? This does contradict the position in charity law. In Thornton $v$ Howe ${ }^{19}$ a trust for printing, publishing and propagating the sacred writings of Joanna Southcote (which were alleged to declare, maintain or reveal that the Holy Spirit impregnated her and a second Messiah was to be born) was held to be a valid charitable trust for the advancement of religion. The Master of the Rolls, Sir John Romilly, held that although the claimant was, in his opinion, 'a foolish, ignorant woman, of an enthusiastic turn of mind', the Court should not 'make any distinction between one sect and another'.

I want to focus, however, upon the indirect discrimination claim in Ladele.

\footnotetext{
${ }^{15}$ Williams-Drabble v Pathway Care Solutions ET, Case Number: 2601718/2004 (2 December 2004); Fugler v MacMillan - London Hairstudios Limited ET, Case Number: 2205090/2004 (21-23 June 2005); Noah v Sarah Desrosiers (Wedge) [2008] ET, Case Number: 2201867/07 (29 May 2008).

${ }^{16}$ [2008] EWHC (Admin) 1865.

17 [2010] EWCA Civ 80.

${ }^{18}$ Para 15.

${ }^{19}$ Thornton $v$ Howe (1862) 31 Beavan 14.
} 
Both the Court of Appeal and the EAT held that there had been a disadvantage but that it had been justified. The Court of Appeal held that the Council's actions had a legitimate aim: through its Dignity for All policy 'Islington wished to ensure that all their registrars were designated to conduct, and did conduct, civil partnerships as they regarded this as consistent with their strong commitment to fighting discrimination, both externally, for the benefit of the residents of the borough, and internally in the sense of relations with and between their employees'. ${ }^{20}$

It was also proportionate. The Court of Appeal quoted the EAT's statement that 'the only way in which they could have achieved that aim was by requiring all their registrars to conduct civil partnerships'. ${ }^{21}$ The Court of Appeal held: 'the aim of the Dignity for All policy was of general, indeed overarching, policy significance to Islington, and it also had fundamental human rights, equality and diversity implications, whereas the effect on Ms Ladele of implementing the policy did not impinge on her religious beliefs: she remained free to hold those beliefs, and free to worship as she wished'. ${ }^{22}$ Further, Ladele was employed in a public job and was being 'required to perform a purely secular task, which was being treated as part of her job'. ${ }^{23}$

The argument here does seem a trifle one-sided. Surely Dignity for All protects discrimination on grounds of religion as well as sexual orientation? There seems to be no recognition of this. Preventing discrimination on grounds of sexual orientation is described as being of 'overarching, policy significance' whilst freedom of religion is defined very narrowly.

Does freedom of thought, conscience and religion not extend beyond the right to hold beliefs and worship? What about the right to manifest one's religion or belief? This right is found within Article 9 ECHR and it is of note what the Court of Appeal said about the ambit of Article 9.

\footnotetext{
${ }^{20}$ Para 46.

${ }^{21}$ Para 50.

22 Para 51.

${ }^{23}$ Para 52.
} 


\section{Article 9}

I have commented elsewhere ${ }^{24}$ on what I regard to be the recent tendency on the part of the domestic judiciary to interpret the Article 9 rights in a narrow and conservative fashion. In particular, I have questioned the correctness of Lord Bingham's assertion in $R$ (on the application of Begum) v Headteacher and Governors of Denbigh High School ${ }^{25}$ that 'interference [with Article 9] is not easily established ${ }^{26}$ and have shown how lower courts have used this statement to come to the conclusion that Article 9 is not engaged.

The result of this is that Article 9 is rendered of little use. In $R$ (on the application of WatkinsSingh) v The Governing Body of Aberdare Girls' High School ${ }^{27}$ the claimant won because she argued everything but Article 9. And in the recent Court of Appeal decision in $G_{h a i}{ }^{28}$ a Hindu challenging cremation laws won because he persuaded the court to reinterpret laws on cremation rather than using Article 9.

The cases on the Employment Regulations follow this trend. In the recent Court of Appeal decision in Eweida v British Airways ${ }^{29}$ Sedley LJ held that that 'the jurisprudence on Art.9 does nothing to advance the claimant's case'. ${ }^{30}$ And in Ladele the EAT was satisfied that the analysis that they had adopted was not inconsistent with Article 9 ECHR since that had adopted 'a very narrow protection indeed for employees'.

Focusing upon the Court of Appeal decision in Ladele, the same tendency can be seen. The Court of Appeal held that it was right to address the issues in the light of Article 9 ECHR but that, as Lord Hoffmann put it in $R$ (on the application of Begum) $v$ Headteacher and Governors of Denbigh High School ${ }^{31}$ 'Article 9 does not require that one should be allowed to manifest one's religion at any time and place of one's own choosing'. ${ }^{32}$ The Court of Appeal held that this supported the view that 'Ladele's proper and genuine desire to have her

\footnotetext{
${ }^{24}$ M Hill and R Sandberg 'Is Nothing Sacred? Clashing Symbols in a Secular World' [2007] Public Law 488506; R Sandberg, 'Controversial Recent Claims to Religious Liberty' (2008) 124 Law Quarterly Review 213217; R Sandberg, 'The Changing Position of Religious Minorities in English Law: The Legacy of Begum' in R Grillo et al (ed) Legal Practice and Cultural Diversity (Aldershot: Ashgate) 267-282.

${ }^{25}$ [2006] UKHL 15 at para 50.

${ }^{26}$ At para 24.

27 [2008] EWHC (Admin) 1865.

${ }^{28}$ [2010] EWCA Civ 59.

${ }^{29}$ [2010] EWCA Civ 80.

${ }^{30}$ Para 22.

31 [2006] UKHL 15.

${ }^{32}$ Para 54.
} 
religious views relating to marriage respected should not be permitted to override Islington's concern to ensure that all its registrars manifest equal respect for the homosexual community as for the heterosexual community'. ${ }^{33}$

Again the argument is one sided. What about Islington's concern to ensure equal respect for different religious views? On the face of the judgment, this concern doesn't exist.

Moreover, the Court of Appeal held that its assessment was 'reinforced'34 by the Strasbourg jurisprudence which had dismissed Article 9 claims by pharmacists who refused to sell contraceptives, ${ }^{35}$ a Quaker who did not want to pay tax insofar as it was used to finance weapon research, ${ }^{36}$ or an university student who was refused enrolment because of her headscarf. ${ }^{37}$

This is a reference to the Strasbourg Specific Situation Rule which recognises that a person's Article 9 rights may be influenced by the particular situation of the individual claiming that freedom. It is true that this rule applied to these three cases. This principle is not of universal application: it only applies where someone has voluntarily submitted themselves to a system of norms, usually by means of a contract. This voluntary submission creates a 'specific situation' which limits the claimant's right to manifest.

Although Strasbourg has applied this rule in relation to those who voluntarily enters into a contract of employment, ${ }^{38}$ it might be questioned whether Ladele had voluntarily agreed to a contract of employment that included civil partnerships. When Ladele applied for her job, there was no such thing as civil partnerships.

In the Court of Appeal decision in Copsey $v$ WBB Devon Clays Ltd ${ }^{39}$ Rix LJ argued that the Strasbourg jurisprudence did not represent a body of consistent decisions where an employer rather than the employee ought to vary the employee's working hours. ${ }^{40}$ This point seems

\footnotetext{
${ }^{33}$ Para 55.

${ }^{34}$ Para 55.

${ }^{35}$ Pichon and Sajous v France Application 49853/99 (2 October 2001).

${ }^{36}$ C v United Kingdom App. No. 10358/83, 37 ECHR Dec \& Rep 142.

${ }^{37}$ Sahin v Turkey (2007) 44 EHRR 5.

${ }^{38}$ Stedman v United Kingdom (1997) 5 EHRLR 544; Ahmad v United Kingdom (1981) 4 EHRR 126.

${ }^{39}$ [2005] EWCA Civ 932, [2005] I.C.R 1789.

40 See paras 65-66.
} 
relevant here. Let alone, other remarks in Copsey such as those by Mummery LJ who held that the Strasbourg rulings on the specific situation rule were 'repeated assertions unsupported by the evidence or reasoning that would normally accompany a judicial ruling' which were 'difficult to square with the supposed fundamental character of the rights'. ${ }^{41}$

The application of the specific situation rule renders Article 9 impotent allowing other Convention rights to 'trump' it with ease. The Court of Appeal decision in Ladele provides the clearest evidence of this to date. The Court of Appeal noted that these Article 9 judgments provided a 'contrast' to other Strasbourg decisions ${ }^{42}$ which emphasized that 'where sexual orientation is in issue, there is a need for particularly convincing and weighty reasons to justify a difference in treatment regarding rights falling within article $8,{ }^{43}$ In other words, whilst the protection provided by Article 9 is weak, the protection provided by Article 8 is strong.

\section{Religious Exceptions}

Although we are going to deal with the question of religious exceptions in depth in the next session, it might be wise to note of the treatment given of the current exceptions by the Court of Appeal decision in Ladele.

The Court of Appeal considered the exception given to religious groups to discriminate on grounds of sexual orientation in the field of employment. ${ }^{44}$ The Court of Appeal stated that this exception 'identifies the relatively limited circumstances in which it is permissible to discriminate against anyone on grounds of sexual orientation on grounds of religion or belief'. ${ }^{45}$

Of interest here is the fact that the Court of Appeal sought to stress the narrow scope of the exceptions. Moreover, although it is frankly unsurprising that the Court held that the exception did not apply to Ladele, the tenor of the judgment is still noteworthy.

\footnotetext{
${ }^{41}$ See paras 30-39.

${ }^{42}$ Salguerio da Silva Mouta v Portugal (2001) 31 EHRR 47 and EB v France (2008) 47 EHRR 21.

${ }^{43}$ Para 59.

${ }^{44}$ Employment Equality (Sexual Orientation) Regulations 2003 reg 14.

${ }^{45}$ Para 70.
} 
The Court of Appeal held that ' the prohibition of discrimination by the 2007 Regulations takes precedence over any right which a person would otherwise have by virtue of his or her religious belief or faith to practice discrimination on the ground of sexual orientation'. ${ }^{46}$ The exception did not protect Ladele since this was 'self-evidently a secular activity carried out in a public sphere under the auspices of a public, secular body'. ${ }^{4}$ It followed that not only was it unlawful for Ladele to refuse to perform civil partnerships but also the Council had no alternative but to insist upon her performing such duties. ${ }^{48}$

For Dyson LJ, 'the legislature has decided that the requirements of a modern liberal democracy, such as the United Kingdom, include outlawing discrimination in the provision of goods, facilities and services on grounds of sexual orientation, subject only to very limited exceptions. ${ }^{49}$

Again, we see the 'trumping' of religious freedom. The importance of not discriminating on grounds of sexual orientation is stressed but the importance of not discriminating on grounds of religion is ignored. Surely that is equally contrary to the will of the legislature. Moreover, and this is a point which can be kept back for our discussion of exceptions in the next session, the fact that the exceptions are open to religious groups (variously defined) clearly leaves religious individuals at a disadvantage.

Other cases have underscored this. In McFarlane $v$ Relate Avon $L t d^{50}$ it was decided that a Christian counsellor dismissed for failing to give an unequivocal commitment to counsel same-sex couples was not discriminated against on grounds of religion or belief. In McClintock $v$ Department of Constitutional Affairs ${ }^{51}$ a Justice of the Peace who resigned (since he could not in conscience make an order placing children with same-sex couples as permitted by section 79 of the Civil Partnership Act 2004) was unsuccessful in his claim of religious discrimination because he had never made it plain that his objection was underscored by conscientious or religious objection.

\footnotetext{
${ }^{46}$ Para 69.

${ }^{47}$ Para 70.

${ }^{48}$ Para 71.

${ }^{49}$ Para 73.

50 [2009] UKEAT 0106_09_3011 (30 November 2009).

51 [2007] UKEAT/0223/07/CEA, also discussed above at para 279.
} 


\section{Conclusions}

It should be rather clear by now that I am uneasy as to some of the reasoning in the Ladele case but why should this matter what are the wider implications of the judgment?

First, it is worth noting that together with Eweida (which concerned a much narrower argument) Ladele is the highest authority we have on religion or belief discrimination law. The judgment and reasoning is thus likely to be influential.

In relation to direct discrimination, I do not doubt for a second that the decision is correct. And hopefully this will lead to a more prudent use of the direct discrimination provisions. A tendency to argue 'everything but the kitchen sink' undermines the worth of the argument and is off-putting to the decision-maker. However, there seems to be a degree of hostility towards religious claims. Would the comments about not making remarks out of context appear in sex discrimination claim or a race discrimination claim? The focus purely upon the motive of the discriminator seems to create a rather large hurdle.

In relation to indirect discrimination, I am uneasy at how the laudable aim of preventing discrimination on grounds of sexual orientation is used to annihilate the claim of religious discrimination. The one-sided nature of the argument is buttressed by a now well-established but ultimately flawed narrow interpretation of Article 9. This is particularly regrettable in the case of Ladele where it is arguable that the specific situation rule ought not to apply at all. Not all marriage registrars instantly became civil partnership registrars so how can it be argued that she voluntarily agreed to this, bearing in mind she was appointed when the law and social mores were very different to the current situation? I also find it of concern how the fact that Ladele had been willing to carry out other functions outside her contract was used against her.

I think the tenor and reasoning in Ladele is more important than the decision. And the tenor and reasoning is important for anyone - religious or not - who considers freedom of thought, conscience and religion to be an important right. I am not saying that the 'religion or belief' argument always needs to win but I am saying that it needs to be considered seriously and treated as being as important as other rights. And I'm not sure that is the case at the moment. 